\title{
Psychological injury in the two World Wars: changing concepts and terms in German psychiatry
}

\author{
RUTH KLOOCKE \\ Charité Universitätsmedizin Berlin \\ HEINZ-PETER SCHMIEDEBACH* \\ Universität Hamburg \\ STEFAN PRIEBE \\ Queen Mary, University of London, and Charité Universitätsmedizin Berlin
}

\begin{abstract}
This paper describes how German psychiatrists in two World Wars treated psychologically injured soldiers, and the concepts of related illnesses which they developed. The literature is reviewed, and symptomatolgy of patients and therapeutic practice in the wars are compared. By 1916 German psychiatrists had already established a concept of illness that continued to be used until World War II and beyond, albeit with a changing terminology. The vague term 'war neurosis' was commonly used, but covered different, partly overlapping concepts. Psychiatrists considered the disorder as a psychogenetic reaction based on an individual predisposition and denied a causal link between the experience of war and subsequent psychopathology. It may be concluded that psychiatrists developed theoretical models and practical treatment methods in a manner that met the social and military requirements of the time.
\end{abstract}

Keywords: history; military psychiatry; models of illness; post-traumatic stress disorder; psychogenic; psychological; shell-shock; society; trauma; 'war neurosis'; World War I; World War II

* Address for correspondence: Institut für Geschichte und Ethik der Medizin, UKE Hamburg, Martinistraße 52, 20246 Hamburg, Germany. Email: p.schmiedebach@uke.uni-hamburg.de 


\section{Introduction}

The two World Wars represented watersheds in the way the psychiatric profession dealt with psychological traumas. It was the first time that these occurred in the context of war action in socially relevant numbers. Not only was there a substantial burden on the state through pension claims, but discipline and fighting morale in the Army were jeopardized by the quasi infectious spreading of the so-called 'war neuroses'. This mass phenomenon changed the attitude of psychiatry in a significant way. The practice of treatment and compensation was increasingly aligned to the norm of what was socially acceptable. The rejection of applications for compensation became standard practice among psychiatrists. The therapeutic goal was, above all, to restore the patients as far as possible to fitness for work. The involvement of the medical profession in the two World Wars can be seen as part of the process that the German social historian Lutz Raphael (1996) dubbed 'Verwissenschaftlichung des Sozialen' (the handing over of social problems to science). This applied particularly to psychiatry, which had by now become established in modern medicine and was scientifically legitimized to control social and cultural relations. ${ }^{1}$

In the course of this development a change appeared in the models of illness - or rather in the terms used by German psychiatrists to talk about psychological trauma - which lasted for decades. Terms which suggested a causal link between an experience and psychological reaction were replaced by a terminology which pointed to the constitution of the person affected. This development began shortly after the outbreak of World War I and continued into World War II. Three important moments can be identified which were significant for the development of the changed concept of the illness: the so-called 'Kriegstagung', a conference of leading German psychiatrists and neurologists on the war, held in Munich in 1916; legislation on insurance in 1926; and the banning of the term 'war neurosis' in 1944. The model of illness established by the end of WWII, which described symptoms as 'abnormal reaction' on the basis of individual disposition, determined the practice of assessment and therapy in German-speaking countries for decades.

There are already valuable publications in medical history on the way psychological trauma was handled in the two World Wars. ${ }^{2}$ The aim of this contribution is to build on these publications, to delineate and compare the changes in the concepts of the illness and to discuss the nebulous term 'war neurosis'. We argue that the uncertainty in the use of the term and concept of 'war neurosis' was due to the combined effects of social aspects, medical knowledge, professional interests of psychiatrists and psychotherapists, and political and military goals. We would also like to consider the spectrum of the various conditions which determined the psychiatric discussion on what 
was called 'war neurosis'. First, we give a brief overview of the type of patient, the symptoms observed and the therapeutic measures adopted.

\section{Patients and symptoms}

According to contemporary sources during the early months of WWI, 'war neurosis' did not exist. Although there were a number of soldiers who had experienced nervous breakdowns, this was not yet seen as a real threat to the strength of the Army. By the end of 1914, however, with the Army digging trenches across the Western Front, an epidemic of 'war neurosis' began to materialize. ${ }^{3}$ Symptoms included uncontrollable shaking, and disturbances of speech, vision, hearing or gait, all without a detectable organic basis. A number of concrete traumatic situations seemed to be linked to the emergence of these symptoms. For example, there were soldiers who developed blindness after a gas attack and others who became deaf after enduring long periods of shellfire. Soldiers who were forced to crouch down in a shell crater covered by the torn body of a comrade reacted by developing dumbness; being buried alive for hours or days could induce uncontrollable shaking, trembling or spasms (Binswanger, 1922). However, despite the obvious correlation between traumatic events and the emergence of symptoms, by no means all those who had to endure such incidents developed these symptoms. It seemed that the particular mental disposition of the individual mediated between the traumatic event and the psychological symptom, so that trauma was not regularly followed by similar symptoms or indeed any symptoms at all.

Although there are official records for nervous illnesses in WWI, exact numbers are difficult to establish. The official records identify 613,047 cases who suffered from 'nervous illness' during WWI (Heeressanitätsinspektion des Reichswehrministeriums [hereafter HR], 1934: 145; see also Hilpert, 1995: 70-1). Neurological illnesses, e.g., epilepsy or progressive paralysis, also came under this heading. The records on the percentage of psychogenic disorders ('hysteria', 'psychopathy', 'nervous shock') vary from 65 to $80 \%$, i.e., the total number may well have been in the order of 400-490 thousand. This figure does not take into account multiple admissions and omits those who were never treated. The population of all patients with nervous illness out of all casualties increased from $2.2 \%$ in $1914 / 15$ to $3.5 \%$ in $1916 / 17$, with a slight reduction to $2.9 \%$ in $1917 / 18$ (HR, 1934: 146). The term 'war neurosis' does not feature in the official records. Based on the official records, Paul Lerner (2001: 141) estimates 200,000 'war neurotics', without specifying which diagnostic labels he includes in this number.

Blaßneck (2000: 12, 34-9) points out that there is no official record of the military casualties in WWII. There is an unpublished 'Vorläufiger Sanitätsbericht des deutschen Heeres 1939-45' (preliminary medical report) by Hans Müller in the Archives of the Sanitätsamt der Bundeswehr in Bonn. 
Müller reports a consistent frequency of the diagnosis 'war neurosis' of about 3-5\% of all admissions to military hospitals between 1939 and 1945. Other authors state an increasing frequency of the diagnosis, for example, Oswald Bumke in 1942 (quoted by Schneider, 1984: 65; see also Hilpert, 1995: 703). Roth (1987: 72) calculates a figure of about 20-30 thousand persons suffering from 'war neurosis' between spring 1941 and the beginning of 1944 , and assumes that at the beginning of 1945 the number amounted to up to 100,000 persons. Roland Müller (2001: 150) has a much higher estimate of at least 472,500 'war neurotics' in WWII.

Although the number was considerable in WWII, the disorder did not have the same relevance as in WWI. Until spring 1941, 'war neurosis' did not plague the German armies as it had done in WWI. Soldiers suffering from mental and physical strain more often showed psychosomatic reactions, for example peptic ulcers (Berger, 1998: 112). Eventually, there were so many of them that they were put together in special 'stomach battalions' in which all soldiers shared the same diet. What can be observed here is a shift or transformation in the nature of psychological injury from the hysteric expressive type prevalent in WWI to a more inward-oriented type. It is difficult to find a convincing explanation for this shift. One possible reason is that, based on lessons learned from WWI, all young recruits had to undergo an extensive medical examination, which considered their mental health as well as physical fitness (Blaßneck, 2000: 31). Potential recruits deemed mentally unfit were not taken into the Army. Another reason could be that 'war neurosis' is intimately linked with a particular type of warfare, i.e., trench warfare. Mobile warfare, which was used more extensively in WWII, may not have promoted the same type of psychological response. However, from spring 1941 onwards, the picture changed. ${ }^{4}$ The 'war neurosis' that had been epidemic in WWI began to reappear. Age seemed to be a predisposing factor: very young and very old soldiers were those most affected.

In summary, it can be stated that to some extent similar reactions to the mental and physical strain of warfare occurred in both the World Wars. However, there was a significant change in the type and frequency of symptoms: in WWI, disorders of perception and shaking were most frequent, while in the early months of WWII psychosomatic reactions of the locomotion and gastrointestinal systems were predominant, and they persisted despite the resurgence of 'war neurosis' from 1941 onwards.

\section{Treatment}

Until 1915/16, most soldiers suffering from psychological injury due to warfare were discharged from military service and received pensions. In 1917, however, the same patients were re-examined, and in some cases pensions were withdrawn (Hoffmann, 1920; see also Riedesser and Verderber, 1996: 70). Patients originally discharged and pensioned were required to 
appear before so-called 'Invaliden-Prüfungs-Geschäfte' (invalid examination boards) (Lerner, 1997: 135).

Re-examinations occurred annually, and many of the 'neurotics' who had been previously discharged as incurable were subjected to a new system of treatment. Treating war neurosis was endowed with particular significance for the economy and the war effort of the nation. The doctors were at the centre of a dynamic system that sought to improve reduced human performance and to use the remaining working capacity as efficiently as possible. Healing was conceptualized as enabling the patient to work. Patients were classified into different groups depending on their remaining abilities to fight or to do useful work in civilian areas. The acts of diagnosing, treating, and rehabilitating were separated, and hospital stays were kept as short as possible. The hospital was viewed as an unfavourable place for neurotics. Throughout Germany, workshops were added to military hospitals and new hospitals were constructed in agricultural settings and near factories. A rational system regulating the flow of 'neurotic' soldiers was introduced. Akin to an assembly line - to use Lerner's phrase - 'neurotics' were first separated from malingerers and the chronically mentally ill (Lerner, 2000: 18). Then individuals for whom treatment was deemed worthwhile were sent to specialized stations where so called 'active treatment' was administered, alongside certain forms of psychotherapy. Different forms of aversive therapy were included under the heading of 'active treatment'. These were effective with a mixture of hypnosis, discipline and punishment. ${ }^{5}$

The best known methods were the techniques of suggestive hypnosis developed by the Hamburg neurologist Max Nonne (1917) and the so-called 'Kaufmann cure' (1916). Nonne's particular method of hypnosis worked through suggestion. He listed three conditions necessary for his method to succeed: absolute self-confidence on the part of the doctor, complete subordination on the part of the patient, and the creation of an atmosphere in which the success of the cure was a foregone conclusion. Nonne's method gained national attention after he demonstrated his technique at the 1916 Conference in Munich (Lerner, 2003: 76).

The second method of 'active treatment', Kaufmann's technique, combined painful sensations caused by electric current with military exercises and commands. It consisted of four components: first the patient was informed that the treatment would be painful, but successful; second, the patient experienced a series of painful sensations caused by electric current followed by physical exercises; third, military subordination was enforced and the patient had to follow military orders. The fourth component was the doctor's conviction that the treatment, once started, must not be terminated before a complete remission of symptoms was achieved. If the doctor relented, the symptoms would become fixed and irreversible. Kaufmann claimed that his method was superior to Nonne's hypnosis: it required less skill than hypnosis which always carried the risk - according to Kaufmann - that the treatment could cause the patient to be resistant to being cured. 
However, electrotherapy met growing opposition. Alarmed by reports of deaths and serious injuries in late 1916 and 1917, several doctors became concerned about its abuse (Christen, 1917). Patients took their complaints against particular doctors to their political representatives. Medical brutality in general was discussed in the Bavarian Landtag (Lerner, 1996b: 325). In June 1918, psychiatric therapy in the military and field hospitals in Germany was discussed in the German Reichstag (Lerner, 1996b: 326). In August 1918 the Bavarian War Ministry directed doctors to act with more moderation (Lerner, 1996b: 317). The Ministry was concerned that the impression was being given that some doctors were making diagnoses and treatment plans according to financial interests, i.e., reducing the cost of war pensions, rather than in the interest of the health of the patient.

Alongside these aversive treatments, doctors influenced by psychoanalysis became involved in the treatment of 'war neurotics' (Freud, 1919: 5). Particularly active in this field were Karl Abraham, Sandor Ferenczi and Ernst Simmel. They reported their experience at the Fifth International Congress on Psychoanalysis in Budapest in September 1918 (Zur Psychoanalyse ..., 1919). Simmel practised the 'cathartic hypnosis' method, a precursor of the psychoanalytic method. Abraham and Ferenczi developed forms of short-term psychotherapy appropriate to military hospitals. As a theoretical model, Freud saw the symptoms as founded in a conflict within the ego. The conflict between the old peace-time ego and the new, martial ego of the soldier became acute as soon as the peace-time ego recognized the extent to which the actions of his newly-formed parasitic double endangered his life (Freud, 1919: 5). The healthy individual, however, was supposedly able to suppress his love for himself and his instinct of self-preservation in the service of overriding ideas, to 'sacrifice his ego for the whole' (Abraham, 1919: 34). The psychoanalytical idea of a 'flight into illness' as a mechanism working unconsciously in 'war neurotics' was soon adopted by established psychiatrists. The psychoanalysts involved saw the treatment of 'war neurotics' not least as a chance to prove the efficacy and practical relevance of the psychoanalytic technique and in this way to improve acceptance of psychoanalysis (Freud, 1919: 3). Official representatives of the Army attended the Congress in Budapest. The setting up of psychoanalytical research wards was planned, as Freud (1919:3) reported - not without pride - but they were not realized because WWI ended.

With the beginning of WWII, psychiatrists made use of the experience of WWI (Roth, 1987: 33). Electrotherapy was used again, but in a modified form, and was in the tradition of the aversive treatments, often referred to as the 'torture methods', of WWI, (e.g., Berger, 1998: 108; Müller, 2001: 123-26; Roth, 1987). On the other hand, a psychotherapeutic approach was also favoured by the Heeressanitätsinspektion (Inspectorate for the Army Medical Services). A distinct rivalry developed between the two forms of therapy (Roth, 1987; Schröder, 1993). In the Air Force and in services with 
highly qualified experts, milder forms of psychotherapy, hypnosis, autogenic training or depth psychology were primarily used. It was obvious that treating a pilot with a painful current did not necessarily restore his ability to fly an aircraft. The Army on the other hand set up a strictly organized system of 'active treatment'. Friedrich Panse, a psychiatrist at the army hospital at Ensen, modified the 'Kaufmann cure' ${ }^{6}$ He used galvanic current applied to the whole body surface, combined with suggestive hypnosis. Patients resisted this procedure as it caused serious pain to the skin; it was therefore necessary to put them in shackles. In December 1940 it was still necessary to obtain the patient's consent for this form of therapy. In January 1943, however, when the military situation became more and more critical and the number of war neurotics increased, the Supreme Army Command revised its former policy and ruled that treatment with galvanic current did not require the consent of the patient (Hilpert, 1995: 44).

The continuance of the war resulted in an increasing number of military casualties, and a new system was established for re-evaluating the capacity of war neurotics to do military duty (Blaßneck, 2000: 55-67; Riedesser and Verderber, 1996: 172-4). Unlike the situation in WWI, the system of managing war neurotics was now no longer oriented towards work in the civilian sector. Instead, the focus was on the wide range of possible military missions for the 'psychopathic' soldier. An elaborate system of assignment was combined with a threat to the soldier's life. Moreover, unlike the situation in WWI, 'war neurotics' could not possibly be discharged with a pension. The intensified selection and treatment of 'war neurotics' began in the summer of 1942 .

For physically and mentally exhausted soldiers, resting places and recreation areas were made available. The soldiers who did not recover were sent to special wards for people with nervous injuries or disorders in army hospitals where they were treated with the aim of making them fit for front-line duty again. Those who remained resistant to treatment (in general 'active treatment'), were transferred to one of the following: lunatic asylums with special wards for mentally ill soldiers, special services of the Reserve Army, or delinquent battalions. If they did not recover or were unable to carry out their duties, they were court-martialled or sent to a concentration camp. The special services of the Reserve Army functioned as training services for 'maladjusted' soldiers. If the soldiers were deemed to have resisted because of 'bad character', they were transferred to delinquent battalions.

The treatment of 'war neurotics' was basically similar in both World Wars. The military psychiatrists in WWII built on the experience of WWI, carried out an even more thorough sifting out of potential 'war neurotics' and set up strictly organized structures with the purpose of gradually re-integrating neurotics into active service. In both World Wars there was a strong, professionally motivated rivalry between psychotherapeutic approaches and the processes of 'active treatment'; psychotherapy, however, remained a marginal phenomenon, used on only a few 'war neurotics'. The aversive 
therapies used were based on the principles of discipline, deterrence and punishment. The increasing radicalization of the threatened measures also reflects the helplessness of the medical staff faced with a spreading epidemic of 'war neuroses'. The explicit target that affected soldiers should return to the front-line was only achieved for a few 'war neurotics', and even among those there were often relapses (Müller, 2001: 137). It becomes clear that the threat the 'war neurotics' faced, a threat which was integrated in the very concept of the treatment, reached a new dimension in WWII: the final step in the process for therapy-resistant persons was their possible annihilation.

\section{Changing terms}

'War neurosis', 'war neurotic' and 'the war neurotic question' are terms used in both the World Wars as well as by today's medical historians in the context of psychological disorders occurring in war after traumatic events. Quite different concepts of illness have been subsumed under these terms. It is not clear when the concept of 'war neurosis' was first used. ${ }^{7}$ Lengwiler (2000) does not mention 'war neurosis' at all in his history of military psychiatry in Germany and Switzerland in the period 1870-1914. Together with the laterobsolete 'war psychosis', he gives only the terms 'nervousness', 'male hysteria' and 'states of exhaustion' as diagnostic categories. Wollenberg (1914: 2182) emphasized as early as 1914 'that there is no psychosis or neurosis that is specific to war'.

In the official statistics of the Sanitätsbericht (Report of the Medical Corps) for WWI, the term 'war neurosis' does not appear, nor does the colloquial term 'war trembler'. In this report, 'neurasthenia', 'hysteria' and 'psychopathic disorder' were diagnosed, and much less frequently 'nervous shock', 'psychasthenia' and unspecifically 'neurosis' (HR, 1934: 148). Bonhoffer (1914: 1778), in an article on 'Psychiatry and war', still refers only to 'hysterical conditions' on the basis of a 'psychopathic constitution'. It can be observed that the nebulous, almost popular-science term 'war neurosis', which did not really fit into the contemporary psychiatric nosology, appeared in academic discussion only when the tendencious element of the disorder was more emphasized, i.e., its closeness to malingering or to so-called Begehrungsreaktion (desires for gain reaction).$^{8}$ Equally one can postulate that medical historians use the term 'war neurotics question' most often when identifying presumed tendentious medical behaviour in the psychiatrists of that time, that is, showing how they allowed themselves to be used for political and social purposes. ${ }^{9}$

Originally, what was understood by 'war neurosis' was a form of 'traumatic neurosis' in the Oppenheim (1915) sense. The neurologist Hermann Oppenheim had introduced this term in $1889 .{ }^{10}$ Using a study investigating injured industrial workers with mental ailments, Oppenheim delineated a distinct disease entity that he named 'traumatic neurosis' which reflected a causal relationship between trauma and subsequent medical disorder. 
Oppenheim believed that the origin of the disorder was an undetectable microscopic change in the brain caused by cerebral concussion. However, he also accepted that psychological processes played an aetiological role (Schmiedebach, 1999). In 1916 a professional debate on the subject was held in Munich, and Oppenheim's position was rejected by a majority of the psychiatrists and neurologists attending. ${ }^{11}$ The favoured approach was to view the disorder as a product of the mind, not the body. The success of hypnosis and suggestion in reducing symptoms fostered the acceptance of this psychogenic approach. The rejection of Oppenheim's position and the widespread acceptance of psychogenicism had a profound effect on the use of the term 'traumatic neurosis'; it was almost completely abandoned.

The expression 'war neurosis' now stood for disorders in the spectrum of hysterical and neurasthenic diseases and was used as a common collective term to cover various concepts of illness; see, for example, Lewandowsky (1917). On the one hand, by using the term 'war neurotic' one was able to avoid the diagnosis 'male hysteria' which was felt to be a stain on a man's honour. On the other hand, the term 'war neurosis' reflects the important influence of the psychological concept of neurosis. Psychiatrists treated psychoanalysis with considerable reserve, yet the implementation of the psychogenic approach in psychiatry did undoubtedly reflect psychoanalytic ideas (see Komo, 1992: 94-103; Roth, 1987: 17-33). According to the psychogenic approach, symptoms were caused by a more or less unconscious desire to flee from war into illness. These Begehrungsvorstellungen (desires for gain), such as the desire to stop fighting and receive a military pension, were seen as engendering a general disposition towards neurosis. Soon, doctors began to see this attributed 'constitution' as inferior and connected it with the so-called 'psychopathic constitution'. The doctrine of the 'psychopathic constitution' had become established at the end of the nineteenth century. It categorized socially deviant behaviour in terms of the prevailing values of order and selection (Raphael, 1996: 175). 'Psychopathy' was explicitly not given the status of illness; this constitution in a person simply did not fulfil a postulated norm or it led to a reduced ability to perform (Komo, 1992: 86). The deviation from the norm was attributed to an inferior genetic disposition. Aschaffenburg (1922) distinguished, for example, 'constitutionally depressive', 'compulsively ill', 'unrealistic', 'agitated', 'unstable', 'pathological liars' and 'sexual deviants'. To identify such individuals at an early stage and exclude them from military service was seen as an important task of military psychiatry, since as 'troublemakers' and 'failures' they would endanger the order and success of military operations (Komo, 1992: 87). The concept of 'psychopathy' was always subservient to the idea of performance, i.e., it was in essence an instrument for the optimal use of human resources through selection. The norm is not to be understood, as elsewhere in medical contexts, as a statistical norm, but as an ultimately ideological, normative value in the sense of 'socially desirable behaviour'. 
Initially 'neurasthenia' also came under the heading of 'war neuroses'. It had originally been a fashionable late-nineteenth century diagnosis designating an understandable 'nervous exhaustion' as the result of unusual psychological strain. ${ }^{12}$ In the description of their symptoms, 'neurasthenics' hardly differed from 'war neurotics with psychopathic constitution'. In retrospect, the borderline between 'natural', understandable 'neurasthenic' reactions to psychological strain and the allegedly genetically determined 'psychopathic' reaction seems arbitrary (Müller, 2001: 45). Characteristically, 'neurasthenia' was a diagnosis given to higher ranks whereas 'hysterical reactions' were restricted to the lower ranks, and this underlines the social implications of the diagnoses (Gaupp, 1922: 89). The criterion of the 'understandable' - the evaluation of behaviour as 'natural' - points to greater sympathetic acceptance on the part of the doctors. 'Neurasthenia' shared this greater level of acceptance with what was called 'acute reaction to shock', which designated short-term, psychological reactions to traumatic events - reactions that later disappeared completely. These were also considered 'understandable'. However, there were doctors at the time who demanded that 'war neurotics' should be taken seriously as sick men und who warned against the effect of a lack of acceptance on those affected (Komo, 1992: 79).

The professional controversies over methods of treatment had an effect on the use of the terminology: from today's perspective it is possible to note that only those patients who were deemed appropriate for 'active treatment' were called 'war neurotics', whereas those who were to be treated with rest and psychotherapeutic measures continued to receive the diagnosis 'neurasthenic'. This meant that in the course of WWI a clear standardization in the evaluation by experts took place, and the conceptual field of 'war neurosis' began to narrow down to 'psychogenic (hysterical) reaction' based on a socalled 'psychopathic constitution' (Gaupp, 1922: 86). The most important consequence drawn from the doctrine of 'psychopathy' was that 'war neuroses' were regarded as not requiring compensation. The genesis of the condition was decisively attributed to 'psychopathic constitution' as the socalled endogenous individual factor; a causality between the experience of war and the symptoms of illness was fundamentally denied. Any compensation or granting of a pension was considered to be detrimental to the course of the illness, since the symptoms might thereby become permanent. As early as 1916, at the War Conference of neurologists and psychiatrists in Munich, questions of compensation and pensions were discussed in this spirit. ${ }^{13}$ The assessment of patients by expert witnesses changed during the course of the war. Ewald Stier saw the administrative treatment of nervous disorders as the central problem of the war pension administration. According to his account, the rejection of unjustified pension claims in the interest of the national economy was the main task of an expert evaluating cases (Stier, 1922: 186) ${ }^{14}$ Neurotic illnesses were increasingly placed alongside the Begehrungsreaktion or malingering. The observation that 'hysterical 
reactions' hardly ever occurred among prisoners of war served as an important argument here. Gaupp's interpretation, for example, was to the effect that prisoners of war could expect no benefit from these symptoms, no benefit in the sense of a dispensation from front-line duties, compensation or pension. ${ }^{15}$ On the other hand, in the case of active soldiers at the front a 'war neurosis' was, as a rule, a more or less conscious Zweckreaktion or reaction with a purpose, namely to get out of the danger zone or to gain other advantages. Similarly, 'pension wish neurosis' was also referred to (Moser, 1991).

The experiences of WWI left clear traces in the National Insurance Regulation passed in 1926. Following essentially the line taken by Stier and Bonhoeffer, the National Insurance Office made a formal decision on 24 September 1926 that inability to work, or disability based on 'the idea of being ill' or on 'more or less conscious wishes', did not require compensation (Feilchenfeld, 1927: 274). The forms of illness so far described as accident-, imprisonment-, war- and pension-neuroses were interpreted as 'reaction based on wishes' or 'psychologically understandable reaction to the fact of insurance and to the procedure for compensation as such' (Feilchenfeld, 1927: 275). Stier emphasized expressly that it is 'not a case of real illness ... but only psychologically understandable reactions'. He claimed that the concept of hysteria was obsolete, whereas the term 'physical or psychological constitution' was of particular significance. Interestingly this position did not go unchallenged. In a circular from the Minister of Labour of 1929 the following guidelines were given, among others:
Objections have been raised to the practice of deducing a psychopathic disposition purely from the appearance of neurotic symptoms. ... It has been found that the labelling of patients in short formulations such as 'psychopath', 'neuropath', 'pension hysteric', 'psychopathic', 'neuropathic disposition' were felt hurtful and insulting and these will cease to be used in expert opinions and records. (Horn, 1932: 79)

This shows that contemporaries also noticed and criticized the bias of those writing psychiatric reports.

Many psychiatrists who had been active in WWI still practised in WWII and based their work on the same ideas. The 'Guidelines for the acquisition of military medical experience' first of all made a distinction between 'nervous exhaustion', which corresponded to the earlier 'neurasthenia', and 'hysterical reactions' (Berger, 1998: 110). ${ }^{16}$ This categorization of psychological reactions, which was largely taken over from WWI, was modified a number of times in the course of WWII (Valentin, 1981, quoted by Berger, 1998: 110-12). Before the outbreak of WWII the expression 'neurosis' had been questioned as being vague and open to interpretation (Blaßneck, 2000: 14-17). There were many attempts and initiatives aimed at doing without the term neurosis altogether. In June 1944 the Supreme Army Command 
ordered that the term 'neurosis' should be dropped and replaced by abnorme seelische Reaktion (abnormal mental reaction). Labels such as 'war neurotic', 'war trembler' and 'war hysteric' were explicitly prohibited. ${ }^{17}$ A distinction was made between 'abnormal reactions to experience' as purely psychological reaction and the so-called 'psychogenic functional disorders' (Blaßneck, 2000: 17). The latter covered traditional 'hysterical' symptoms such as trembling, psychogenic paralysis, etc., and also disorders of the bladder, stomach and intestines and similar complaints from the psycho-somatic field, which appeared in increasing numbers in WWII.

Various reasons can be identified as to why, in WWII, certain terms were discredited or given up as being derogatory. Characteristically the changes in terminology were brought about by regulation, i.e., it was an intentional change by the Heeressanitätsinspektion, although the implementation of the changes often lagged far behind. In essence, there were three different types of problems responsible for the change in terminology:

1. The discussions of the concept of neurosis reflect the fundamental dispute between the schools of psychiatry and psychotherapy. Roth (1987) and also Schröder (1993) showed that there was a decisive battle between the two groups over the treatment of 'war neurotics'. In the course of the discussion the psychotherapists were able to establish themselves successfully as an independent professional group of therapists. The concept of neurosis, originally coined by psychoanalysis, was, however, later superseded by the terms 'abnormal reaction to experience' or 'psychogenic reaction' as being neutral regarding their theoretical provenance. These concepts could be used both as part of a psychotherapeutic or a psychiatric model. In practical treatment both schools continued to operate alongside one another in unchanged form up to the end of the war (Roth, 1987: 73). Neither of the two schools of thought was able to establish itself finally as sole authority in the Army.

2. The banning of the terms 'war neurotic', 'war trembler' and 'war hysteric', which layman felt were derogatory, was a reflection of the the Heeresanitätsinspektion's fear of negative public opinion about the way doctors treated psychogenic illnesses. People remembered the end of World War One when there were mutinies following the use of electrotherapy, which the soldiers felt was torture and abuse, and when those affected went to court and brought lawsuits against the military doctors who had treated them. ${ }^{18}$ These lawsuits generally had no consequences for the doctors concerned, but they did significantly modify the attitude of those politically responsible. The psychiatric consultants in the Army constantly admonished the doctors in the field to take these patients seriously as patients and warned against making 
moral judgements on the symptoms (Berger, 1998: 111). The army inspectors placed themselves so to speak protectively between patients and doctors but did not impose negative sanctions on what the doctors in fact did (Müller, 2001: 168-71). However, doctors practising in the military continued to see their main task as detecting malingerers and making those who came for treatment 'usable', that is, fit to go back to the front. The fact that this was not often successful did not alter the final aim at all. The doctors' identification with the public interest was stronger than their sense of responsibility to the particular patient. In his Marburg example, Roland Müller (2001: 146) was able to show with the aid of patients' files that doctors became downright opponents or persecutors of their patients.

3. The banning of the terms 'war neurotic', 'war trembler' and 'war hysteric' was also a continuing part of the debate on pensions. The military authorities intended to avoid any term that suggested a causal relationship between war and psychological disorder. From 1916, trauma as a causal element of mental disorder was consistently and continuously denied by psychiatric professionals. The Heeressanitätsinspektion tried on the one hand to limit the effect of the negative attitude to patients held by doctors in the corps. On the other hand, however, the doctors were not released from their task of acting in the public interest and fending off pension claims. The ambivalence of this task cannot be overlooked. The credo of the debate about 'pension-wish neurosis' - that the symptoms only arose from the possibility of getting a pension and that those affected would become fit for work as soon as they received notice of final refusal - conflicts with the encouragement given to take the 'war neurotics' seriously as 'real patients'.

\section{Conclusion}

The following concepts merged into the nebulous term 'war neurosis': the remains of 'traumatic neurosis' in the sense Oppenheim used it; a concept of neurosis with its notion of psychogenesis of physical disorders which was influenced by psychoanalytical terms; the traditional hysteria concept; and the psychopathy concept of constitutional inferiority. The gradually dying concept of neurasthenia also found its way into this concept field.

When we examine the question of the continuous existence of the one disease, we conclude that 'war neuroses' occurred in the First and Second World Wars in a similar way. Yet it is worth remarking that in WWII the symptoms shifted towards psychosomatic forms of reaction. The concept of the illness as formulated in 1916 by the overwhelming majority of German psychiatrists was an 'abnormal reaction' based on individual disposition, and this definition remained the consensus of opinion in WWII and after it. 
Despite this conceptual continuity we find several changes in terminology. There were up to six terms in use at the same time. Psychiatrists created the different terms pointing to the alleged cause of the disorder ('war neurosis') or with reference to similar disorders ('hysterical reaction'). Some referred to constitutional factors ('psychopathic reaction') and others alluded to social and economic consequences. Thus we also find the expression 'war neurosis' in connection with the so-called 'pension neuroses' with their Begehrungsvorstellungen (desires for gain) and the question of malingering. The overtone of the concept 'war neurosis' always implies the socially undesirable, or a tendency to abusive behaviour requiring containment. This is the way in which it differs, for example, from 'neurasthenia' or 'acute shock reaction', which were seen as 'imaginable' or 'understandable'. Contemporaries were aware of the ambivalence of the concept field, and consequently there were many attempts to simplify the terminology and distance it from concepts with negative connotations.

Towards the end of WWII the leading military psychiatric authority established the more descriptive term of 'abnormal reaction to experience' as the official label for a purely psychological disorder and the term 'psychogenic functional disorder' for complaints with physical symptoms. The changes in terminology intended by the Heeressanitätsinspektion were aimed at avoiding certain areas of conflict in the discussion of 'war neuroses': Among the changes intended were the banning of the concept of neurosis, the abandoning of obviously derogatory terms and also the avoidance of terms that suggested any causal link between the war and the symptoms. This attempted standardization of terminology with a tendency towards a more descriptive form of expression was not, however, ultimately used and, in practice, polypragmatism prevailed in the use of terms. The terms 'war neurosis', 'hysterical reaction', 'psychopathic reaction', 'desire neurosis', 'pension wish neurosis' and even 'traumatic neurosis' were still in use after the end of WWII.

The treatment of 'war neurotics' in WWI embraced a rich spectrum of methods, including aggressive forms of treatment as well as psychotherapeutic approaches. The most frequently used aggressive methods led to public protests and rebellion at the end of the war. In order to avoid similar reactions or to prevent 'war neuroses' from appearing at all, an intensified sifting out of predisposed individuals was undertaken at the medical examination for military service. Despite this procedure medical and military authorities were forced to realize that psychogenic disorders appeared again in WWII. In the course of the war, methods of treatment of 'war neurotics' became increasingly radical. In 1942, at the latest, stricter selection of those affected was introduced. The threat of court martial or concentration camp meant potential danger to life - in other words, the threat exerted by the therapeutic arsenal took on a new quality.

The methods of treatment used by psychiatrists in both World Wars need to be seen against the background of the role played by psychiatry in Germany since 1870. Psychiatry was established in academia and, at the same time, claimed responsibility for defining the standards of mental 
abilities required to perform certain social and professional tasks in society. In the two World Wars psychiatrists saw a chance to apply this goal to one particular aspect of society: military efficiency. Psychiatric concepts, and particularly methods of treatment, were used to optimize human resources in warfare. In both World Wars individual health and performance was thus redefined in terms of the collective needs of German war efforts.

\section{Notes}

1. At the beginning of the twentieth century, the establishment of psychiatry at German Universities had just been completed; see: Blasius, 1994; Dörner, 1984; Engstrom, 2003; Eulner, 1970; Kaufmann, 1995; Schmiedebach, 1986; Schmiedebach, 1995.

2. On the manner in which psychological trauma was treated in the First World War in Germany, see: Kaufmann, 1999; Komo, 1992; Lembach, 1998; Lerner, 1996a, 1996b, 1997, 2000, 2003; Micale and Lerner, 2001; Riedesser and Verderber, 1996; Roth, 1987. For WWII the following studies dealt with the question: Berger, 1998; Blaßneck, 2000; Hilpert, 1995; Komo, 1992; Müller, 2001; Riedesser and Verderber, 1996; Roth, 1987.

3. Many contemporary authors pointed out that the war neuroses first appeared in any number with the beginning of trench warfare; see, for example: Heeressanitätssinspektion des Reichswehrministeriums, 1934: 147.

4. Roth (1987: 39) refers to the quarterly report of advising psychiatrists: Vierteljahresberichte der Beratenden Psychiater 1940/41, Bundesarchiv-Militärarchiv. Freiburg im Br., RH 12-23 (H20)/468, 481-7.

5. On 'active treatment' in WWI, see: Lembach, 1998: ch. 4; Lerner, 2003: ch. 4.

6. For the history of the modified electrotherapy used by Friedrich Panse (1899-1973), see Hilpert, 1995.

7. Studies in medical history (e.g., Blaßneck, 2000; Komo, 1991; Lembach, 1998; Müller, 2001; Roth, 1987) give no information on this. Blaßneck (2000: 13) does, however, point out that the concept is not clearly defined for WWII.

8. See, e.g., Robert Gaupp at the War Conference in Munich, reported by Lilienstein (1916: 1228): 'There is no such thing as special war neurosis, any more than a special traumatic neurosis.' Gaupp, however, in later passages refers to 'the war neurotics' in a general sense, e.g., 'The war neurotics are mostly not wounded' (Lilienstein, 1916: 1229).

9. See, e.g., Komo (1992: 70) and Riedesser and Verderber (1996: 36). On the jacket of their book, Riedesser and Verderber describe themselves clearly as 'non-neutral' historians with a brief to uncover the entanglement of military psychiatrists in political goals. In our depiction, we too speak of 'war neurotics', not in a strict diagnostic sense but to describe the phenomenon in general.

10. On the history of the term, see Fischer-Homberger (1975). According to this author (p. 29), Oppenheim's first publication on 'traumatic neurosis' appeared in 1888. On the biography of Hermann Oppenheim (1857-1919), see Lerner, 2003: 27-31.

11. See the so-called Kriegstagung (Lerner, 1996b: 79-144). In fact, this meeting in Munich included two professional meetings: on 21-22 September 1916 a meeting of the Deutscher Verein für Psychiatrie, and on 22-23 September 1916 (partly overlapping) a meeting of the Gesellschaft Deutscher Nervenärzte. Almost all neuropsychiatrists were members in both associations. Proceedings of the meetings were published in: Allgemeine Zeitschrift für Psychiatrie und psychisch-gerichtliche Medizin, 73, 163-233 (1917); Ärztliche Sachverständigen-Zeitung, 22, 36-9, 249-52 (1916); Berliner Klinische Wochenschrift, 53, 1228-31 (1916); Deutsche Zeitschrift für Nervenheilkunde, 56, 1-216 (1917); Neurologisches 
Centralblatt, 35, 792-824 (1917); Psychiatrisch-neurologische Wochenschrift, 18, 262-5, 275-7 (1916/17).

12. On the history of the concept of neurasthenia, see: Gjiswijt-Hofstra and Porter, 2001; Radkau, 1998.

13. Paul Lerner (2003: 33) explains Oppenheim's defeat at this Conference with the fact that, according to his approach, the 'war neurotics' would have had to be discharged from duty on a pension just like soldiers who had suffered physical injuries.

14. In fact, as Lerner (2003: 33) points out, the number of post-traumatic pension applications never exceeded $1-2 \%$ of all accident insurance claims.

15. See, e.g., Gaupp's speech on 22 Sept. 1916, reported by Mendel (1916: 797).

16. Berger (1998) quotes the 'Richtlinien für das Sammeln kriegsärztlicher Erfahrungen', 10 October 1939, Bundesarchiv-Militärarchiv Freiburg (RH 12-23, H.20/488).

17. Decree issued by the Oberkommando der Wehrmacht (Supreme Commander of the German Army), 30 June 1944; see Roth, 1987: 68.

18. Best known is the lawsuit against the Vienna psychiatrist and neurologist Julius WagnerJauregg, in which Sigmund Freud testified as expert witness (Eissler, 1979).

\section{References}

Abraham, K. (1919) Erstes Korreferat. In: Zur Psychoanalyse der Kriegsneurosen. Internationale Psychoanalytische Bibliothek, Bd. 1 (Leipzig \& Wien: Internationaler Psychoanalytischer Verlag), 31-41.

Aschaffenburg, G. (1922) Die konstitutionellen Psychopathen. In O. v. Schjerning (ed.), Handbuch der Ärztlichen Erfahrungen im Weltkriege 1914/1918. Bd. IV, Geistes- und Nervenkrankheiten (Leipzig: J. A. Barth), 122-53.

Berger, G. (1998) Die Beratenden Psychiater des deutschen Heeres 1939 bis 1945 (Frankfurt a. M.: Peter Lang).

Binswanger, O. (1922) Die Kriegshysterie. In O. v. Schjerning (ed.), Handbuch der Ärztlichen Erfahrungen im Weltkriege 1914/1918. Bd. IV, Geistes- und Nervenkrankheiten (Leipzig: J. A. Barth), 45-67.

Blasius, D. (1994) "Einfache Seelenstörung”. Geschichte der deutschen Psychiatrie 1800-1945 (Frankfurt a. M.: Fischer Taschenbuch).

Blaßneck, K. (2000) Militärpsychiatrie im Nationalsozialismus (Würzburg: Deutscher WissenschaftsVerlag).

Bonhoeffer, K. (1914) Psychiatrie und Krieg. Deutsche Medizinische Wochenschrift, 40, 1777-9.

Christen, T. (1917) Schädigung durch Sinusstrom. Deutsche Medizinische Wochenschrift, 43, $1536-7$.

Dörner, K. (1984) Bürger und Irre. Zur Sozialgeschichte und Wissenschaftssoziologie der Psychiatrie (Frankfurt a. M.: Europäische Verlagsanstalt).

Eissler, K. R. (1979) Freud and Wagner-fauregg vor der Kommission zur Erhebung militärischer Pflichtverletzungen (Wien: Löcker).

Engstrom, E. J. (2003) Clinical Psychiatry in Imperial Germany. A History of Psychiatric Practice (Ithaca \& London: Cornell University Press).

Eulner, H.-H. (1970) Die Entwicklung der medizinischen Spezialfächer an den Universitäten des deutschen Sprachgebietes (Stuttgart: Ferdinand Enke), 257-82.

Feilchenfeld, L. (1927) Lehrbuch der praktischen Versicherungsmedizin (Berlin: Georg Stielke).

Fischer-Homberger, E. (1975) Die traumatische Neurose (Bern: Hans Huber).

Freud, S. (1919) Einleitung. In: Zur Psychoanalyse der Kriegsneurosen. Internationale Psychoanalytische Bibliothek. Bd. 1 (Leipzig \& Wien: Internationaler Psychoanalytischer Verlag), 3-8. 
Gaupp, R. (1922) Schreckneurosen und Neurasthenie. In O. v. Schjerning (ed.), Handbuch der Ärztlichen Erfahrungen im Weltkriege 1914/1918. Bd. IV, Geistes- und Nervenkrankheiten (Leipzig: J. A. Barth), 68-101.

Gijswijt-Hofstra, M. and Porter, R. (eds) (2001) Cultures of Neurasthenia from Beard to the First World War (Amsterdam: Rodopi).

Heeressanitätsinspektion des Reichswehrministeriums [HR] (1934) Sanitätsbericht über das Deutsche Heer im Weltkriege 1914/18, Vol. 3 (Berlin: Mittler \& Sohn).

Hilpert, R. (1995) Rekonstruktion der Geschichte eines speziellen Elektrosuggestivverfahrens ("Pansen") aus Archivmaterialien des Heeressanitätswesens der Wehrmacht und dessen Einordnung in das Kriegsneurosenproblem des Zweiten Weltkrieges. Diss. med. dent., Leipzig University.

Hoffmann, R. A. E. (1920) Über die Behandlung der Kriegshysterie in den badischen Nervenlazaretten. Zeitschrift für die gesamte Neurologie und Psychiatrie, Originalien, 55, 143.

Horn, P. (1932) Praktische Unfall- und Invalidenbegutachtung (Berlin: Julius Springer).

Kaufmann, D. (1995) Aufklärung, bürgerliche Selbsterfahrung und die "Erfindung” der Psychiatrie in Deutschland, 1770-1850 (Göttingen: Vanderhoek \& Ruprecht).

Kaufmann, D. (1999) "Widerstandfähige Gehirne" und "kampfunlustige Seelen". Zur Mentalitäts- und Wissenschaftsgeschichte des I. Weltkriegs. In M. Hagner (ed.), Ecce Cortex: Beiträge zur Geschichte des modernen Gehirns (Göttingen: Wallenstein-Verlag), 206-23.

Kaufmann, F. (1916) Die planmäßige Heilung komplizierter psychogener Bewegungsstörungen bei Soldaten in einer Sitzung. Münchner Medizinische Wochenschrift, 63, 802-4.

Komo, G. (1992) Für Volk und Vaterland. Die Militärpsychiatrie in den Weltkriegen (Münster \& Hamburg: Lit-Verlag).

Lembach, F. (1998) Die "Kriegsneurose" in deutschsprachigen Fachzeitschriften der Neurologie und Psychiatrie von 1889 bis 1922. Diss. med., Mannheim University.

Lengwiler, M. (2000) Zwischen Klinik und Kasene. Die Geschichte der Militärpsychiatrie in Deutschland und der Schweiz 1870-1914 (Zürich: Chronos).

Lerner, P. (1996a) "Ein Sieg deutschen Willens": Wille und Gemeinschaft in der deutschen Kriegspsychiatrie. In W. U. Eckart and C. Gradman (eds), Die Medizin und der Erste Weltkrieg (Pfaffenweiler: Centaurus), 85-107.

Lerner, P. (1996b) Hysterical men: war, neurosis and German mental medicine, 1914-1921. PhD dissertation, Columbia University.

Lerner, P. (1997) Rationalizing the therapeutic arsenal: German neuropsychiatry in World War I. In M. Berg and G. Cocks (eds), Medicine and Modernity: Public Health and Medical Care in Nineteenth- \& Twentieth-Century Germany (Cambridge: Cambridge University Press), 121-48.

Lerner, P. (2000) Psychiatry and casualties of war in Germany, 1914-18. Fournal of Contemporary History, 35, 13-28.

Lerner, P. (2001) From traumatic neurosis to male hysteria: the decline and fall of Hermann Oppenheim, 1889-1919. In M. S. Micale and P. Lerner (eds), Traumatic Pasts. History, Psychiatry and Trauma in the Modern Age, 1870-1930 (Cambridge \& New York: Cambridge University Press), 141-71.

Lerner, P. (2003) Hysterical Men: War, Psychiatry, and the Politics of Trauma in Germany, 1890-1930 (Ithaca \& London: Cornell University Press).

Lewandowsky, M. (1917) Was kann in der Behandlung und Beurteilung der Kriegsneurosen erreicht werden? Münchner Medizinische Wochenschrift, 47, 1028-31.

Lilienstein (1916) 8. Jahresversammlung (Kriegstagung) der Gesellschaft deutscher Nervenärzte. Berliner klinische Wochenschrift, 53, 1228-31.

Mendel, K. (1916) VIII. Jahresversammlung der Gesellschaft deutscher Nervenärzte (Kriegstagung) in München am 22. und 23. September 1916. Neurologisches Centralblatt, 35, 792-824. 
Micale, M. S. and Lerner, P. (eds) (2001) Traumatic Pasts. History, Psychiatry and Trauma in the Modern Age, 1870-1930 (Cambridge \& New York: Cambridge University Press).

Moser, G. (1991) Der Arzt im Kampf gegen "Begehrlichkeit und Rentensucht" im deutschen Kaiserreich und in der Weimarer Republik. Fahrbuch für kritische Medizin, 16, 161-83.

Müller, R. (2001) Wege zum Ruhm. Militärpsychiatrie im II. Weltkrieg (Köln: PapyRossa Hochschulschriften).

Nonne, M. (1917) Über erfolgreiche Suggestivbehandlung der hysteriformen Störungen bei Kriegsneurosen. Zeitschrift für die Gesamte Neurologie und Psychiatrie, 37, 191-218.

Oppenheim, H. (1888) Wie sind die Erkrankungen des Nervensystems aufzufassen, welche sich nach Erschütterung des Rückenmarkes, insbesondere Eisenbahnunfällen, entwickeln? Berliner klinische Wochenschrift, 25, 166-70.

Oppenheim, H. (1889) Die traumatischen Neurosen nach den in der Nervenklinik der Charité in den letzten 5 fahren gesammelten Beobachtungen (Berlin: August Hirschwald).

Oppenheim, H. (1915) Der Krieg und die traumatischen Neurosen. Berliner klinische Wochenschrift, 52, 257-61.

Radkau, J. (1998) Das Zeitalter der Nervosität (München \& Wien: Carl Hanser).

Raphael, L. (1996) Die Verwissenschaftlichung des Sozialen als methodische und konzeptionelle Herausforderung für eine Sozialgeschichte des 20. Jahrhunderts. Geschichte und Gesellschaft, 22, 165-93.

Riedesser, P. and Verderber, A. (1996) "Maschinengezwehre hinter der Front". Zur Geschichte der deutschen Militärpsychiatrie (Frankfurt a. M.: Fischer Taschenbuch).

Roth, K. H. (1987) Die Modernisierung der Folter. 1999. Zeitschrift für Sozialgeschichte des 20. und 21. Fahrhunderts, 2, 8-75.

Schmiedebach, H.-P. (1986) Psychiatrie und Psychologie im Widerstreit: die Auseinandersetzung in der Berliner Medizinisch-Psychologischen Gesellschaft (1867-1899) (Husum: Matthiesen).

Schmiedebach, H.-P. (1995) Die Psychiatrie an der Charité auf dem Weg zur Disziplin zwischen Erziehung und Therapie. In P. Schneck and H.-U. Lammel (eds), Die Medizin an der Berliner Universität und an der Charité zwischen 1810 und 1850 (Husum: Matthiesen), 111-23.

Schmiedebach, H.-P. (1999) Post-traumatic neurosis in nineteenth-century Germany: a disease in political, juridical and professional context. History of Psychiatry, 10, 27-57.

Schneider, R. J. (1984) Streßbedingter Zusammenbruch in der Wehrmacht: Konsequenzen für die heutigen Streitkräfte. Wehrpsychologische Untersuchungen, 19 (2), 53-83.

Schröder, C. (1993) Die berufspolitischen Auseinandersetzungen von Psychiatern, Psychotherapeuten und Psychologen in der Wehrmacht zwischen 1938 und 1945. Zeitschrift für Medizinische Psychologie, 2, 132-42.

Stier, E. (1922) Rentenversorgung bei nervösen und psychisch erkrankten Feldzugsteilnehmern. In O. v. Schjerning (ed.), Handbuch der Ärztlichen Erfahrungen im Weltkriege 1914/1918. Bd. IV, Geistes- und Nervenkrankheiten (Leipzig: J. A. Barth), 168-93.

Valentin, R. (1981) Die Krankenbataillone. Sonderformationen der deutschen Wehrmacht im Zweiten Weltkrieg. Schriftenreihe Erfahrungen des deutschen Sanitätsdienstes im Zweiten Weltkrieg, Bd. 2 (Düsseldorf: Droste Verlag).

Wollenberg, R. (1914) Nervöse Erkrankungen bei Kriegsteilnehmern. Münchner Medizinische Wochenschrift, 44, 2181-3.

Zur Psychoanalyse der Kriegsneurosen. Internationale Psychoanalytische Bibliothek, Bd.1 (Leipzig \& Wien: Internationaler Psychoanalytischer Verlag, 1919). 